Indonesian Journal of Electronics and Instrumentation Systems (IJEIS)

Vol.8, No.2, October 2018, pp. 201 210

ISSN (print): 2088-3714, ISSN (online): 2460-7681

DOI: $10.22146 /$ ijeis.39682

\title{
Low Cost Sensor Node Device for Monitoring Landslides
}

\author{
Lukman Awaludin*¹, Oktaf Agni Dhewa ${ }^{2}$ \\ 1,2Electronics and Instrumentation Laboratory, Universitas Gadjah Mada, Yogyakarta, Indonesia \\ e-mail: *11 lukman.awaludin@ugm.ac.id, ${ }^{2}$ oktaf.ad@mail.ugm.ac.id
}

\begin{abstract}
Abstrak
Tanah longsor merupakan salah satu bencana yang sering terjadi di Indonesia dan bencana tanah longsor merupakan natural disaster. Oleh sebab itu bencana ini tidak dapat dihilangkan namun dapat diminimalisir kerugian yang ditimbulkan dengan suatu mekanisme peringatan dini. Sistem peringatan dini mengandalkan suatu node sensor yang digunakan untuk membaca kondisi tanah dengan parameter-parameter tertentu. Parameter-parameter yang dibaca mengarah kepada pendeteksian pergerakan tanah. Dengan keketatan proses pemantauan tentunya diperlukan suatu node sensor yang handal. Namun demikian, terdapat tantangan bagaimana meminimalisir kerugian yang terjadi atas kerusakan node sensor saat terjadi longsor. Node sensor dibuat menggunakan sensor IMU untuk memantau pergerakan tanah dan menggunakan dua pemroses yaitu mikrokontroler dan mini SBC yang biaya pembuatannya murah serta tidak memerlukan space yang besar dalam instalasi-nya..
\end{abstract}

Kata kunci-sensor tanah longsor, node sensor berbiaya murah, sistem peringatan dini, node sensor nirkabel

\begin{abstract}
Landslides are one of the natural disasters that often occur in Indonesia. Therefore, this disaster cannot be eliminated, but it can minimize the disadvantage caused by an early warning mechanism. Early warning systems rely on a sensor node used to read soil conditions with specific parameters. Those parameters that are read lead to the detection of mass movements. With the tightness of the monitoring process, of course, a reliable sensor node is needed. However, there are challenges in how to minimize losses that occur due to damage to sensor nodes when landslides occur. Sensor nodes are made using IMU sensors to monitor mass movements and its use two processors, namely microcontroller and mini SBC, which are inexpensive to manufacture and do not require large space in the installation.
\end{abstract}

Keywords—landslide sensor, low cost sensor node, early warning system, wireless sensor node

\section{INTRODUCTION}

Natural disasters can occur anywhere and anytime. Indonesia is one of the areas prone to natural disasters, one of which is landslides. Landslides are the displacement of slopeforming material in the form of rock, debris material, soil or a mixture of the forming material which moves down [1]. Landslides are a disaster which is a natural disaster. Therefore, this disaster cannot be eliminated, but it can minimize the losses caused by an early warning mechanism. At this time several early warning systems and management of landslide hazards

Received October $15^{\text {th }}, 2018$; Revised October $25^{\text {th }}$, 2018; Accepted October $31^{\text {th }}, 2018$ 
have been developed to reduce the adverse effects that occur. Therefore, an analysis of landslides has received more attention to identifying the relevant physical factors and phenomena as the cause of the soil movement and finally the landslide hazard area is predicted [2].

Tools and methods for monitoring landslides are divided into two ways: first, geometric measurements on the land surface using satellite imagery and aerial photographs; second, observing in the immediate area using a transducer such as an extensometer, inclinometer, geophone, crack meter, and others. This second method can be said as a sensor node on a sensor network which is more precisely a wireless sensor network [3]. Wireless sensor network or often called wireless sensor network (WSN) is a system that has autonomous sensors and is spatially distributed to monitor physical conditions such as pressure, sound, temperature, etc. [4]. Karthik et al. developed and implemented low-cost autonomous WSN for landslide detection with a Self-Energy Harvesting Powered Early Warning System (WSN-SEH). The WSN-SEH contains MEMS sensors, energy harvesting systems, low power embedded controls, an efficient power management system, and a supercapacitor as storage [5].

Currently, the Internet of Thing (IoT) technology has an architecture that can accommodate wireless sensor networks, landslide early warning systems [6]. In addition, in some cases, the use of radio frequency is one solution that can be used, but it is necessary to analyze how to efficiently transmit data on existing sensor nodes to be in a reliable category. As in the study of Sumathi et al. using a Fuzzy techniques method for the efficiency of data handling, the approach in this study uses simulations from NS-2 tools [7]. Giorgetti et al. proposed a WSN design for continuous monitoring and management of landslide hazards. For durability in harsh environments, sensor nodes and particular communication protocols need to be used. So that, the network can organize itself, be adaptive and tolerant of errors. The network mechanism is combined with Time Division Multiple Access (TDMA) in the network layer [2]. In other studies, Oh and Ngo [8] said that to obtain reliable and timely data transmission can use a protocol that is Sharable Slot (SS). SS causes a topology-independent schedule so that the protocol is very responsive to topology changes [8]. Then the study by Chen et al. [9], they examined the reliability of WSN transmission by improving performance with the Inter-Cluster Multi-hop LEACH protocol [9].

Indonesia is an area prone to landslides. 40.9 million people or rather $17.2 \%$ of the population in Indonesia, apparently living in areas prone to landslides. Both in the medium and high-level landslide-prone areas said Sutopo Purwo Nugroho [10]. Many cities in Indonesia are in areas prone to landslides. WSN technology development itself as an early warning system for landslides in Indonesia is done a lot, one of which is a technology developed by Fathani et al. in his research the sensors used were an extensometer, tilt meter, inclinometer, generator, groundwater measurement, ultrasonic water level sensor, IP camera [11]. Besides that, some also use GPS as part of the ground motion sensor. The many uses of sensors will also increase the manufacturing costs of these sensor nodes.

A large number of WSN research and development using radio frequency certainly makes this WSN type useful. However, the challenges faced are the more complex processes in the sensor nodes causing increased power consumption and of course the increasing hardware requirements of the sensor nodes. Besides that, it is also a challenge to communicate using radio frequency itself, which of course must adjust to the existing environmental conditions. Then for WSN that uses IoT technology, it certainly makes this type of WSN more reliable in transmitting data, but for the record that there is no good internet network, this technology will

IJEIS Vol. 8, No. 2, October $2018: 201-210$ 
automatically not function properly. Based on previous studies, namely the development of communication technology and data transmission topology, the types of sensors used and the capabilities of the node itself, then looking at the state of the environment in Indonesia. This paper focuses on how to build the infrastructure of the sensor node itself with the concept lowcost and reliable of the nodes to be reliable as part of an early warning system for landslides.

\section{METHODS}

A WSN into an early warning system by relying on existing sensor nodes, the unity of these sensor nodes is rigitally and certainly senses the state of the parameters in the surrounding environment, which in this case is the movement of the soil to detect landslides or not. These sensor nodes send data to a control center that collects and monitors the data sent. In addition to sending data to the control center, sensor nodes as an early warning system can also perform a warning action to the surrounding environment by sounding a warning such as a siren. It depends on the architecture of the sensor node itself. The illustration of one of the wireless sensor nodes systems is shown in Figure 1. Sensor nodes are indicated by black dots collected in a cluster, and each cluster is connected to the base station.

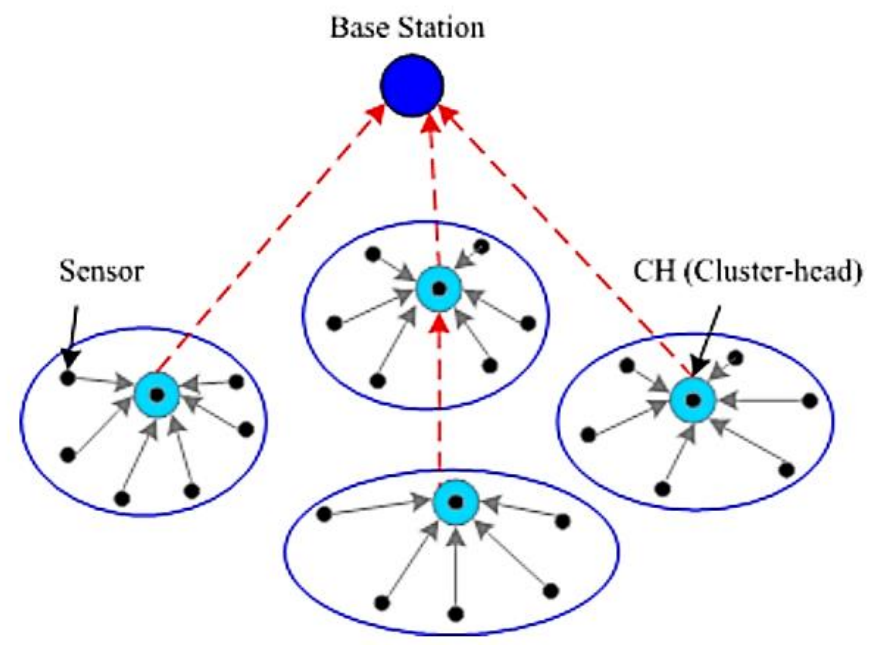

Figure 1. Illustration wireless sensor node architecture [12]

Regards to the importance of the function of a sensor node on WSN, in this paper, proposes a sensor node that is possible to be used in areas prone to landslides does not require extensive space in later installations, reliable, but low-cost. Sensor nodes consist of hardware parts that have sensors; data storage; a processing device; and a transmission device. This hardware is designed to compact and easy to use.

\subsection{System Design}

In this sensor node design is shown how the sensor node architecture is designed. The architecture of this node is shown in Figure 2. The sensors used in this node architecture consist of two parts, namely the parts of the sensors; data storage section; and processing part. The sensors consist of two types, namely temperature and humidity sensors; accelerometer sensor and gyroscope. Temperature and humidity sensors are functioned as indicators of the condition of the hardware node itself. We know, for a possible thing to know the normal status of the performance of a device is to know the condition of the hardware temperature itself. With the presence of a temperature and humidity sensor, we will know the condition of the node at work. Then for the accelerometer and gyroscope sensors are used to monitor the initial position of the 
node on the ground where the node is placed; thus the node can find out if there is ground movement by looking at the translation position of the $\mathrm{x}$-axis, and $\mathrm{y}$ and the position of the angle of the $\mathrm{x}$ and $\mathrm{y}$-axes.

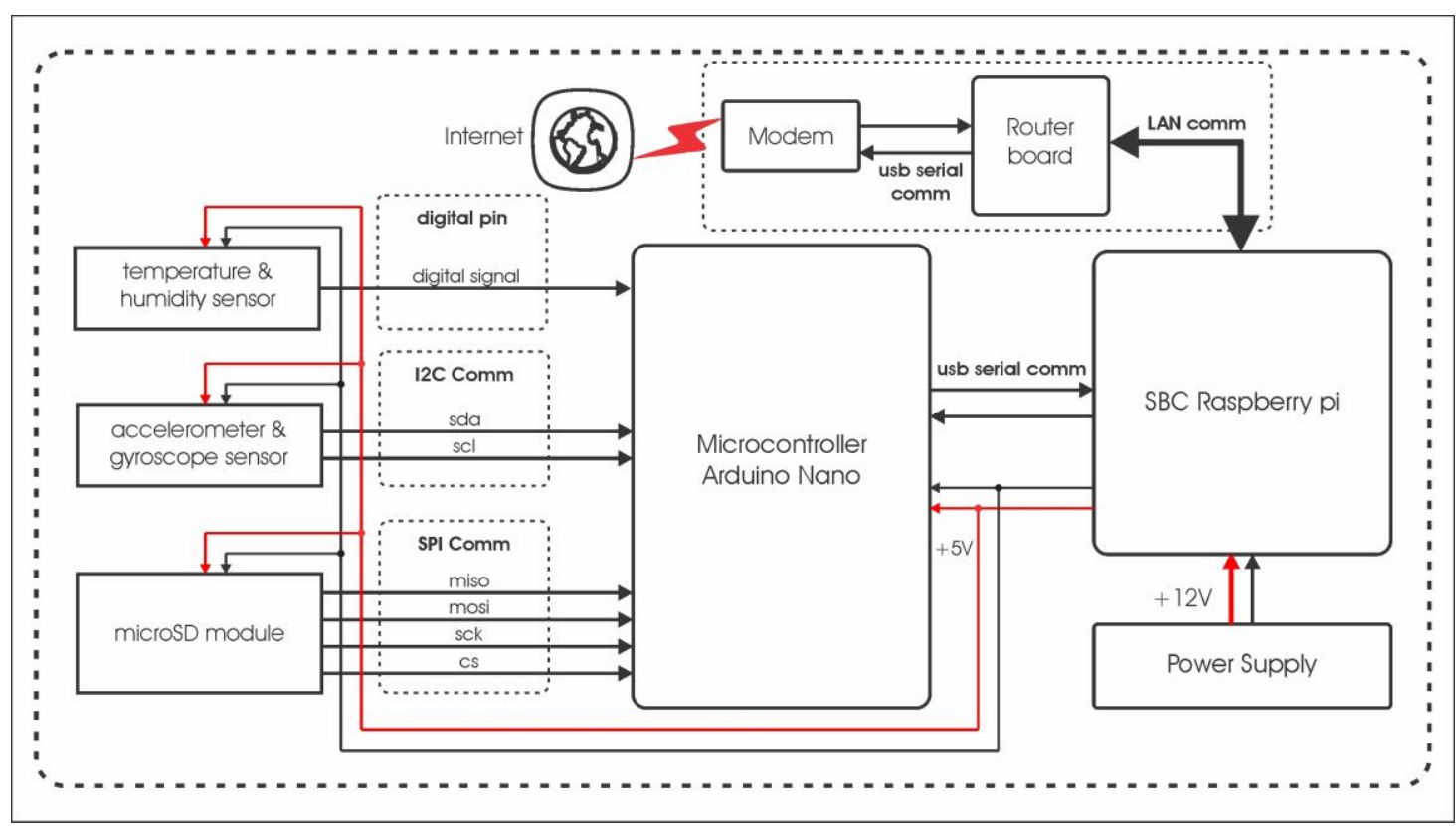

Figure 2. Sensor node architecture

The data storage section is used to store data temporarily at the node, this is needed in addition to log data is also used for data backup if there is a failure in sending data to the monitoring unit (server). The next is the processing part. This part consists of two components, the microcontroller; and a single board computer (SBC). A microcontroller is used to manage and control the retrieval of data from sensors, then SBC is used to process data obtained from the microcontroller. The use of both of these allows for optimal performance processes of sensor nodes. A shield is used to connecting all parts of the sensor node into one compact unit. Figure 3 and Figure 4 show the design of the shield which used. The last part is a transmission device which is consist of a router board and modem for connect to the internet.

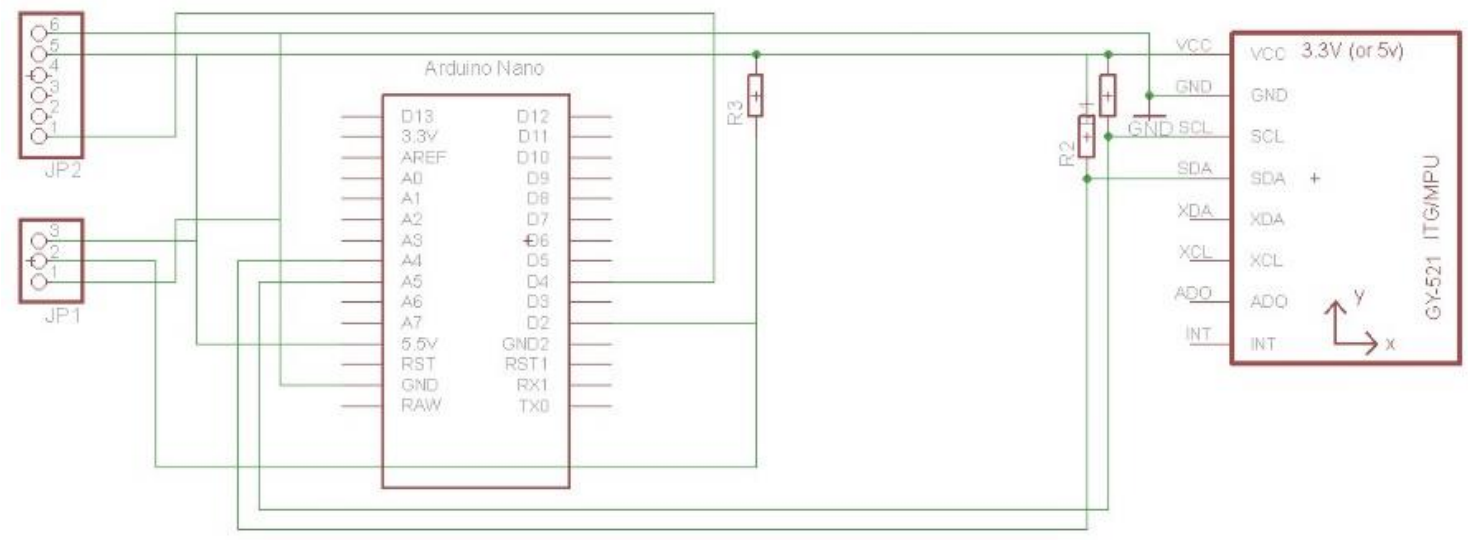

Figure 3. Shield schematic of a sensor node 


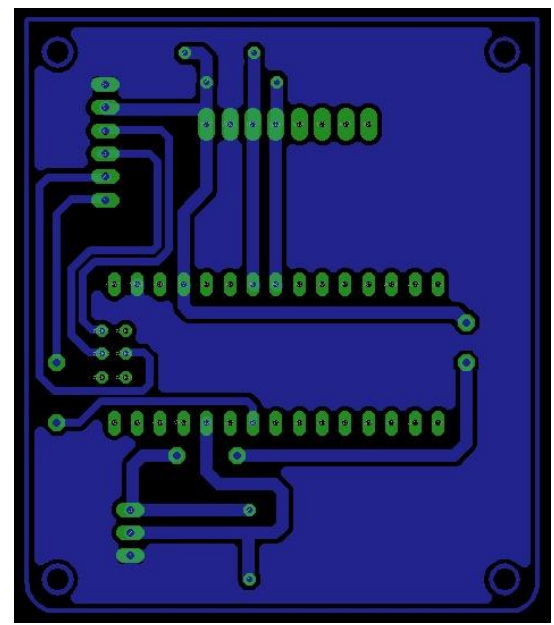

Figure 4. PCB shield design of sensor node

\subsection{Implementation}

The hardware of processing and sensor part of node uses several component modules namely DHT11 (temperature and humidity sensors); MPU 6050 (accelerometer sensor and gyroscope); MicroSD module; Arduino Nano 3.0 ATMega 328 CH340 (microcontroller); and Raspberry pi 3 Model B (single board computer). All of these modules are assembled into a single unit that is compact using the connector of a shield that displays the device as shown in Figure 5. The microSD module used is a micro sd class 4 module. This is chosen because data storage on microSD as data backup does not require high access speeds. Besides that, by using microSD class 4 , it can reduce costs in making this device.

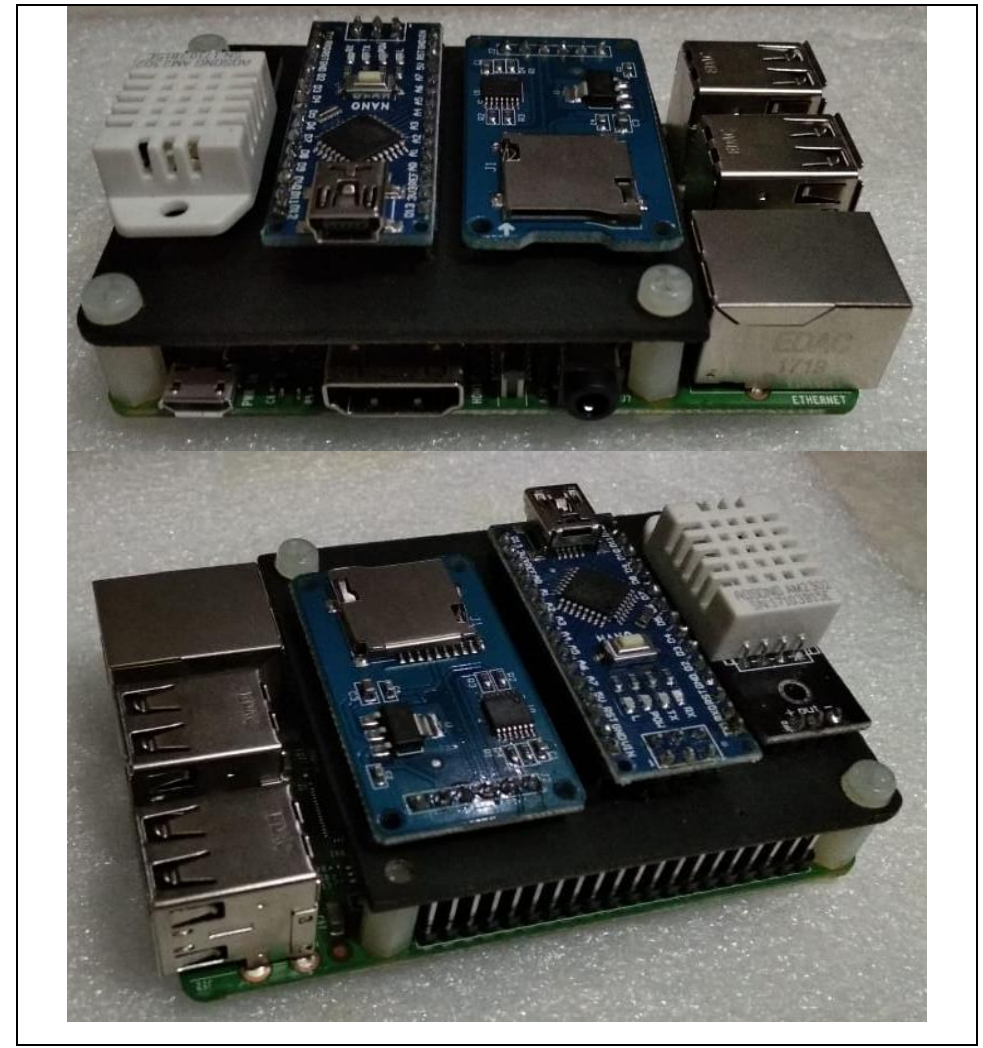

Figure 5. The hardware of processing and sensor part 
The Data Package (Frame Data) is created in a data block with the float data type in the following order:

\section{*Temperature\#Humidity\#Roll\#Pitch\#AcceleroX\#AcceleroY\#AcceleroZ*}

One cycle of the microcontroller process is obtained by one data packet. The angle of the sensor node has a roll angle and a pitch angle. Both types of blades are obtained by calculating the angle of the sensor node using a complementary filter between the accelerometer angle data and the gyroscope angle data. The complementary filter consists of a low pass filter and a high pass filter. The block diagram of the complementary filter shown in Figure 6 and the flowchart of the complementary filter rule shown in Figure 7. Accelerometer angle calculation data is obtained from a rotation matrix calculation, and gyroscope angle calculation is obtained from integral calculations. The accelerometer and the gyroscope data must be valid for filtering processing. This complementary filter is used because it is quite stable and reliable in integrating accelerometer data and gyroscope data [13]. Data transmission uses TCP/IP protocol by utilizing the internet network. The server will request data sent from the sensor node per minute. This scheme is used to facilitate other users if they want to connect with sensor nodes.

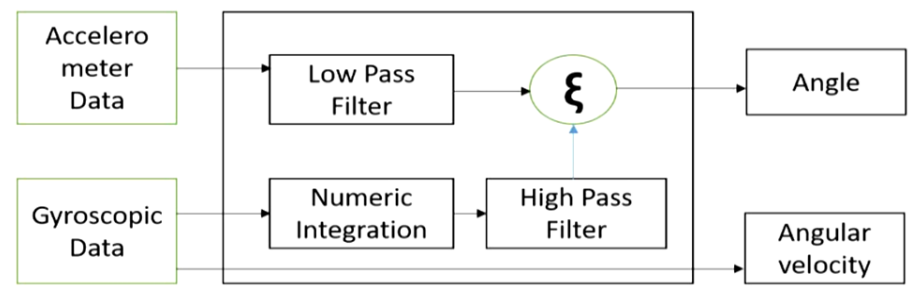

Figure 6. Complementary filter block diagram [13]

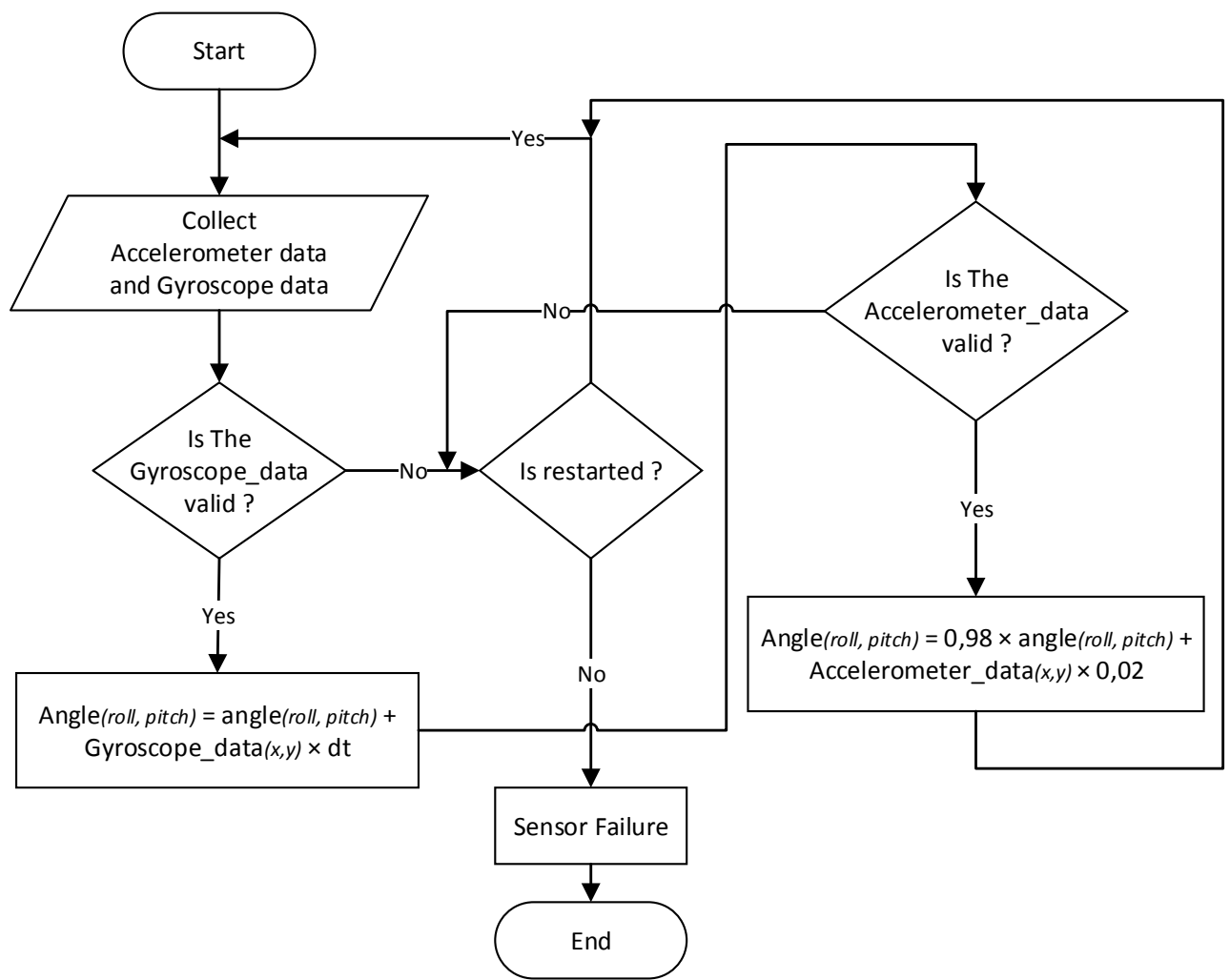

Figure 7. Flowchart of the complementary filter

IJEIS Vol. 8, No. 2, October 2018 : $201-210$ 


\section{RESULTS AND DISCUSSION}

Unit sensors to monitor mass movement conditions around sensor node installations. The dimensions of the processing and sensor devices as shown in Figure 5 are $8.56 \mathrm{~cm} \times 5.65$ $\mathrm{cm} \times 2 \mathrm{~cm}$. With dimensions of the processing and sensor device, it node be compact. The compact shape makes this sensor node easy to apply in the field, as in an area of the city where the area is narrow to place the sensor node. With the addition of a power unit and data transmission unit, the scheme can be mounted separately. Thus the size of the space needed to put the sensor node is not too large. This sensor node becomes a standard device that is low-cost because the device is not more than 1.1 million rupiahs compared to other sensor nodes that use many sensors in it. This is also to reduce losses due to landslides which cause the sensor node to become damaged.

Tests were carried out on each part, namely in the form of accessing the MPU6050 sensor; access to DHT22; microSD module data storage. Also, test the transmission unit of a node sensor. Data which is received by server shown in Table 1. Testing of roll and pitch angles from sensors using complementary filters obtained an error value \pm 2 degrees for reading 0 degrees position. It felt sufficient for the mass movement is basically moving slowly before the landslide and also reduces noise misperception of the data. Data is stored in a microSD card in txt format which is shown in Figure 8.

Table 1. Sensor Node Data

\begin{tabular}{|c|c|c|c|c|c|c|c|c|c|c|}
\hline Date & Month & Year & Time & Temperature & Humidity & Roll & Pitch & AcceleroX & AcceleroY & AcceleroZ \\
\hline 24 & September & 2018 & $04: 03: 45 \mathrm{pm}$ & 30.77 & 59.42 & 1.68 & 7.77 & 0.98 & 0.03 & 0.98 \\
\hline 24 & September & 2018 & $04: 06: 44 \mathrm{pm}$ & 30.76 & 59.80 & 1.53 & 7.86 & 0.99 & 0.03 & 0.99 \\
\hline 24 & September & 2018 & $04: 07: 45 \mathrm{pm}$ & 30.94 & 59.57 & 1.33 & 7.80 & 0.98 & 0.03 & 0.98 \\
\hline 24 & September & 2018 & $04: 08: 42 \mathrm{pm}$ & 30.94 & 59.57 & 1.33 & 7.80 & 0.98 & 0.03 & 0.98 \\
\hline 24 & September & 2018 & $04: 09: 42 \mathrm{pm}$ & 31.37 & 58.10 & 1.62 & 7.84 & 0.99 & 0.03 & 0.99 \\
\hline 24 & September & 2018 & $04: 10: 42 \mathrm{pm}$ & 31.22 & 58.17 & 1.05 & 7.58 & 0.98 & 0.02 & 0.98 \\
\hline 24 & September & 2018 & $04: 13: 44 \mathrm{pm}$ & 30.33 & 60.41 & 1.62 & 8.18 & 0.98 & 0.03 & 0.98 \\
\hline 24 & September & 2018 & $04: 14: 42 \mathrm{pm}$ & 30.33 & 60.41 & 1.62 & 8.18 & 0.98 & 0.03 & 0.98 \\
\hline 24 & September & 2018 & $04: 15: 44 \mathrm{pm}$ & 29.91 & 61.54 & 1.37 & 8.21 & 0.99 & 0.03 & 0.99 \\
\hline 24 & September & 2018 & $04: 16: 44 \mathrm{pm}$ & 30.03 & 61.62 & 1.60 & 8.14 & 0.99 & 0.03 & 0.99 \\
\hline 24 & September & 2018 & $04: 17: 42 \mathrm{pm}$ & 30.03 & 61.62 & 1.60 & 8.14 & 0.99 & 0.03 & 0.99 \\
\hline 24 & September & 2018 & $04: 18: 42 \mathrm{pm}$ & 30.52 & 60.55 & 1.10 & 8.21 & 0.98 & 0.02 & 0.98 \\
\hline 24 & September & 2018 & $04: 19: 44 \mathrm{pm}$ & 30.75 & 59.66 & 1.22 & 8.04 & 0.99 & 0.02 & 0.98 \\
\hline 24 & September & 2018 & $04: 21: 42 \mathrm{pm}$ & 30.82 & 59.34 & 1.70 & 8.08 & 0.98 & 0.03 & 0.98 \\
\hline 24 & September & 2018 & $04: 23: 42 \mathrm{pm}$ & 30.92 & 59.19 & 1.45 & 7.79 & 0.98 & 0.03 & 0.98 \\
\hline
\end{tabular}

Communication of the microcontroller processing unit with Raspberry $\mathrm{Pi}$ is done via serial. The microcontroller used is the Arduino Nano 3.0 type, this is because Arduino has a maximum sampling rate reaching $9000 \mathrm{~Hz}$ compared to Wisense, MicaZ, and BTnode which have a lower sampling rate but the price is higher [14]. This sensor node is designed using two processors because the microcontroller has more role in processing data from the sensor while the SBC Raspberry Pi is currently used to manage data communication to the server and request data from the microcontroller. In this case, the microcontroller as a slave processor and Raspberry $\mathrm{Pi}$ as a master processor. However, later in the development, SBC will be in the program to be able to interpret data (data mining) for further modeling and analysis related to 
ground movements. By distributing work on the sensor node, it will reduce the load from the server if the nodes are connected a lot. Besides, it is intended to develop fault tolerance from nodes to be optimal so that from the beginning the architecture of this node is standardized.

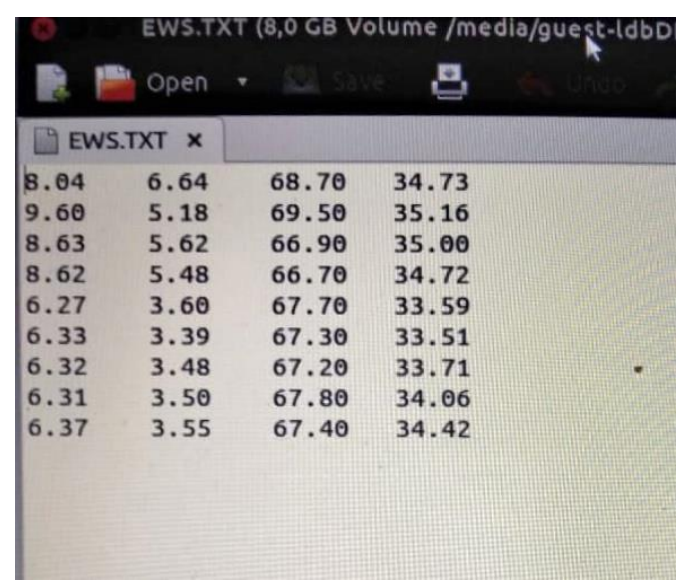

Figure 8. Example of data which is stored in the microSD card

Testing from sending data to the server is done in two ways, namely testing data transmission in the laboratory and testing data transmission while in the field. The data package is sent to the server with the rule every 1 minute of delivery. Delivery using the internet network with a modem. It was chosen because the internet network coverage area in Indonesia is wide enough and to reduce noise and complicated algorithms for shipping if using radio frequency, so the design of this architecture is entirely practically implemented and later reduces the performance load of the nodes.

The results obtained from testing data transmission while in the laboratory data are received usually there are no errors or data loss. However, when the device is installed in the field, the results of the data are sometimes not sent for two minutes or three minutes. Allegations focus on modems that are used against the availability of internet network types (GPRS, edge, 3G, HSDPA, HSDPA +, 4G LTE) in the test environment. Internet modems that move, for example, 4G LTE then to GPRS, the modem takes several minutes to be ready. Well, this is what causes data that is sometimes not sent every minute. Therefore, in using the internet, only one network mode is used. GPRS is chosen because it considers the size of the data sent is quite small. Moreover, the GPRS area in Indonesia is wider. In the future, this research needs to be developed by adding an algorithm that is suitable for SBC for data mining, so that adds the ability of sensor nodes to sensing. Also needs to redevelop the design of a more compact form, especially in the power unit so that the sensor nodes are easy to apply and are more portable.

\section{CONCLUSIONS}

The architecture of the sensor node is made quite compact. Measurement data for angle 0 degrees read \pm 2 degrees, but still reliable as a sensor node for detection of ground movements of low-cost concepts. Data transmission using the internet network to the server unit requires setting one network mode so that there is no interference from the modem waiting time to be stable when switching network mode. In this case, the GPRS mode is chosen by considering the small size of the data sent and the coverage area in Indonesia is more extensive than other network modes, so it is more likely to be applied. 


\section{ACKNOWLEDGEMENTS}

We Gratefully thank the Laboratory of Electronics and Instrumentation and the Department of Computer Science and Electronics, Faculty of Mathematics and Natural Sciences, Universitas Gadjah Mada (research grant number: 0106 / J01.1.28 / PL.06.02 / 2018) for financial support and facilities.

\section{REFERENCES}

[1] I. Iswanto, N. M. Raharja, and A. Subardono, "Sistem Peringatan Dini Tanah Longsor Berbasis ATMega8535," Seminar Nasional Informatika (SEMNASIF), vol. 1, no. 2, May. 2009 [Online]. Available: http://jurnal.upnyk.ac.id/index.php/semnasif/article/view/822. [Accessed: 15-Okt-2018]

[2] A. Giorgetti et al., "A Robust Wireless Sensor Network for Landslide Risk Analysis: System Design, Deployment, and Field Testing," IEEE Sensors Journal, vol. 16, no. 16, pp. 6374-6386, Aug. [Online]. 2016 Available: https://ieeexplore.iee.org/stamp/stamp.jsp?tp=\&arnumber=7488208. [Accessed: 14-Okt2018]

[3] C. Fosalau, C. Zet, and D. Petrisor, "Implementation of a landslide monitoring system as a wireless sensor network," in 2016 IEEE 7th Annual Ubiquitous Computing, Electronics Mobile Communication Conference (UEMCON), 2016, pp. 1-6 [Online]. Available: https://ieeexplore.ieee.org/ielx 7/7763653/7777798/07777813.pdf?tp=\&arnumber=7777813 \&isnumber=7777798. [Accessed: 14-Okt-2018]

[4] S. R. Suryawanshi and U. L. Deshpande, "Review of risk management for landslide forecasting, monitoring, and prediction using wireless sensors network," in 2017 International Conference on Innovations in Information, Embedded and Communication Systems (ICIIECS), 2017, pp. 1-6 [Online]. Available: https://ieeexplore.ieee.org/ielx7/8267166/8275826/08276113.pdf?tp=\&arnumber $=8276113$ \&isnumber=8275826. [Accessed: 14-Okt-2018]

[5] S. Karthik, K. Yokesh, Y. M. Jagadeesh, and R. K. Sathiendran, "Smart autonomous self powered wireless sensor networks based low-cost landslide detection system," in 2015 International Conference on Circuits, Power and Computing Technologies [ICCPCT2015], 2015, pp. 1-4 [Online]. Available: https://ieeexplore.ieee.org/ielx 7/7147630/7159156/07159265.pdf?tp=\&arnumber=7159265 \&isnumber=7159156. [Accessed: 14-Okt-2018]

[6] A. Sofwan, Sumardi, M. Ridho, A. Goni, and Najib, "Wireless sensor network design for landslide warning system in IoT architecture," in 2017 4th International Conference on Information Technology, Computer, and Electrical Engineering (ICITACEE), 2017, pp. 280-283 [Online]. Available: https://ieeexplore.ieee.org/ielx 7/8240802/8257652/08257718.pdf?tp=\&arnumber $=8257718$ \&isnumber $=8257652 \&$ tag $=1$. [Accessed: 14-Okt-2018]

[7] M. S. Sumathi, G. S. Anitha, and N. H. Sridhar, "Efficient data handling of wireless sensor network for real time landslide monitoring system using fuzzy technique," in 2017 International Conference on Circuit ,Power and Computing Technologies (ICCPCT), 2017, pp. $\quad 1-4 \quad$ [Online]. Available: https://ieeexplore.ieee.org/ielx7/8063643/8074159/08074343.pdf?tp=\&arnumber=8074343 \&isnumber $=8074159$. [Accessed: 14-Okt-2018]

[8] H. Oh and C. T. Ngo, "A Slotted Sense Multiple Access Protocol for Timely and Reliable Data Transmission in Dynamic Wireless Sensor Networks," IEEE Sensors Journal, vol. 18, no. 5, pp. 2184-2194, Mar. 2018 [Online]. Available: https://ieeexplore.ieee.org/ielx 7/7361/8277082/08263110.pdf?tp=\&arnumber=8263110\&is number $=8277082$. [Accessed: 14-Okt-2018] 
[9] H. Chen, F. Wang, and M. Zhang, "An improved inter-cluster multi-hop LEACH protocol oriented reliable transmission in WSNs," in 2017 3rd IEEE International Conference on Computer and Communications (ICCC), 2017, pp. 193-197 [Online]. Available: https://ieeexplore.ieee.org/ielx 7/8318023/8322494/08322539.pdf?tp=\&arnumber=8322539 \&isnumber=8322494. [Accessed: 14-Okt-2018]

[10]Anonim, "Frekuensi Bencana Longsor Dari Tahun ke Tahun Terus Meningkat, dan Mencemaskan.”, 16-Dec-2014 [Online]. Available: /artikel/frekuensi-bencana-longsor-daritahun-ke-tahun-terus-meningkat-dan-mencemaskan. [Accessed: 14-Oct-2018]

[11]T. F. Fathani, D. Karnawati, and W. Wilopo, "An Adaptive and Sustained Landslide Monitoring and Early Warning System," in Landslide Science for a Safer Geoenvironment, 2014, pp. 563-567 [Online]. Available: http://link.springer.com/10.1007/978-3-319-050508_87. [Accessed: 14-Okt-2018]

[12]M. Chaw, M. Thein, and T. Thein, "A Framework for Secure and Survivable Wireless Sensor Networks." The Annals of "Dunarea de Jos" University of Galati Fascicle I - 2009. Economics and Applied Informatics. Years XV, 2009, pp. 243-252 [Online]. Available: http://www.ann.ugal.ro/eco/Doc2009/MiChawMonThei_ThandarThein.pdf. [Accessed: 14Okt-2018]

[13]T. Islam, M. S. Islam, M. Shajid-Ul-Mahmud, and M. Hossam-E-Haider, "Comparison of Complementary and Kalman Filter Based Data Fusion for Attitude Heading Reference System" presented at the Proceedings of The 1st International Conference On Mechanical Engineering and Applied Science (ICMEAS 2017), Dhaka, Bangladesh, 2017, p. 020002 [Online]. Available: https://aip.scitation.org/doi/pdf/10.1063/1.5018520. [Accessed: 14Okt-2018]

[14]V. N. Deekshit, M. V. Ramesh, P. K. Indukala, and G. J. Nair, "Smart geophone sensor network for effective detection of landslide induced geophone signals," in 2016 International Conference on Communication and Signal Processing (ICCSP), 2016, pp. $1565-1569$ [Online]. Available: https://ieeexplore.ieee.org/ielx 7/7736795/7754082/07754422.pdf?tp=\&arnumber $=7754422$ \&isnumber $=7754082 \& \operatorname{tag}=1$. [Accessed: 14-Okt-2018] 